\title{
LIGHTING DESIGN IN TWO MOSQUE TYPOLOGIES IN THE CITY OF JEDDAH, SAUDI ARABIA
}

\author{
RAGHDA HARERI \& AREEJ ALAMA \\ Faculty of Human Sciences and Design, King AbdulAziz University, Saudi Arabia
}

\begin{abstract}
Mosques are the most significant building in Muslim communities, where people perform their prayers and gather for social activities. The architecture and design of mosques have undergone significant changes over the centuries due to cultural, economic, and climatic factors. This raises a question regarding the design of the modern mosque. This paper analyses the physical characteristics of two Mosques located in Jeddah city, Saudi Arabia, built at different time periods: the historic Al-Shafi'i Mosque, and the contemporary Al-Farsi Mosque. The analysis focuses on investigating the different design techniques used to lighten the interior space, and how this can be related to the identity of the mosques. In addition, it explores how the orientation of mosques, determined by the Qibla direction, has impacted the indoor lighting quality. This study provides some critical observations demonstrating the importance of the use of light in the mosque's interior, and the essential impact this has on psychological, physiological and behavioural responses of the mosques' visitors, with a focus on both daylighting and artificial lighting.
\end{abstract}

Keywords: artificial lighting, daylighting, orientation, historic mosque, contemporary mosque, indoor lighting quality, interior design, Jeddah, Saudi Arabia.

\section{INTRODUCTION}

The mosque is the heart of the Islamic community. Muslims gather to pray five times a day, exchange news, foster relationships, and organize charitable causes. The Muslims established their first places of worship in open spaces in nature and the first mosque, which was built in 622, was a simple building with a square-plan layout. The main features that most mosques have are a Mihrab (niche), Minbar pulpit), Minaret (tower), Qubba (dome), Sahn (courtyard), Qibla Wall, Ablution Fountain, and Prayer Hall. All Mosques are oriented towards Mecca since the prayers and worship are directed towards this target. To indicate this direction a niche called Mihrab is built into the wall. Since the mihrab (niche) is placed within the inner surface of the southern wall on the longitudinal axis, the vicinity of the mihrab is a dim locality of the entire space [1]. At the right-hand side of mihrab there is the Minbar where the imam gives a speech. Mosques have Qibla wall, a wall in the construction of the mosque that is oriented to Qibla that direct the prayer, orienting the entire building point toward the Qibla axis.

According to Al-Raddadi [2], the design standards for natural lighting can be divided into two parts: the design standards, the natural lighting from the side walls, and the natural lighting from the ceiling. The side walls include the windows, which have different functions. Among the most important features of a mosque are, first, its natural lighting and secondly: ventilation for the mosque's indoor space. The natural lighting of the ceiling creates a balance in the level of illumination intensity. Moreover, the windows of the dome, which is a typical form of the roof, provide a good distributor of the daylight, as taking light from a high level enables the uniform distribution of light [3]. Sources of daylighting are the roof (via skylights or dormer windows) and the walls (windows or full glass walls). Such lighting must be used with care so that glare does not reduce its usefulness by creating visual competition during the religious service [4]. 
According to Eco [5], light is perceived as the common natural element in every substance whether spiritual or material. The more an object is illuminated, the more it appears real. Light is a significant factor that exposes the characteristics, quality and perception of the interior design of a building. Artificial lighting is one of the basic elements that play an important role in creating psychological framework necessary for prayer and reverence, and good distribution ensures it is aesthetically interesting, while avoiding distraction from performing the primary function which is reverence in prayer. In addition, in terms of health considerations, it needs to protect the eyes from stress and prevent accidents and increases the comfort of users of the space. The lighting is often centred around three categories, which are: (1) General lighting: which lights the place and achieves general lighting requirements in a vacuum; (2) Focused lighting: it gives support and more direct light to a specific area or activity such as prayer, mihrab, or pulpit; and (3) Directed Lighting: lighting that is used to accentuate an aesthetic point to draw attention such as the area where the Qur'an is kept or the decorative pattern around the mihrab. To ensure efficient lighting in mosques, consideration should also be given to ensuring a sufficient distribution of natural and artificial light sources. The lighting must be balanced between natural lighting in the morning to afternoon and sunset, followed by artificial light at night. In religious facilities, the design of space and lighting changes according to worship and ritual. Each division of the building requires different lighting [6].

\section{METHODOLOGY}

This qualitative case study takes the form of a comparative analysis. As well as a literature review of relevant articles, a number of documents, including, archived materials and technical drawings were analysed with an objective of understanding the forces and values that influenced the character and design of the investigated mosques.

\subsection{Comparative analysis of case studies}

This study investigated the availability and performance of daylighting and looked into the impact of the Qibla axis on mosque design in two mosque typologies: a historic mosque and a contemporary one. Primary attention was given to examining the mosques' internal architectural components and envelope elements (design and form) in order to determine their impact on daylight provision in the indoor space. An analysis of openings in the envelope, the structural system, the architectural components, the mosque's layout, Mihrab and Qibla wall orientation and form are some of the elements that were investigated, compared, and summarized.

\subsection{Selection criteria}

In order to conduct a cohesive study, two mosques, one historic and the other contemporary were selected. Criteria for selecting these cases included: (1) mosques which had received significant attention from the public and from architects/professionals, (2) mosques with an emphasis on Islamic identity and local materials, (3) mosques with special vernacular architectural considerations and unique design, and (4) mosques from different periods of time in order to study the progress/evolution of mosque layout. Therefore, two mosques were selected in the city of Jeddah: one is an ancient historic mosque (Imam Al-Shafi'i Mosque), and the other is a contemporary one (Al-Farsi Mosque). 


\section{ANALYSIS AND RESULTS}

\subsection{Al-Shafi'i Mosque}

Al-Shafi'i Mosque is one of the oldest mosques in the city of Jeddah, and is considered one of the city's most prominent historical buildings. The name of the mosque is attributed to Imam Muhammad bin Idris Al-Shafi'i. The mosque is still used, and prayer is held the present time. Al-Shafi'i Mosque is located in the Al-Mazloum neighbourhood in Souk Al-Jami, and it is the oldest of its mosques. As the mosque is one of the most important Islamic sites in the city, it illustrates the reality of Islamic practices 1,400 years ago, using traditional materials in the construction process. Al-Shafi'i Mosque is characterized by its construction in the Hijaz style. It was built using marine clay and excavated stone blocks supported by horizontal wooden beams known as takhleh. The mosque is rectangular in shape and stands on an area of $1,638 \mathrm{~m}^{2}$ and a capacity of 1,000 worshippers. Fig. 1 presents the main components and layout of Al-Shafi'i mosque.

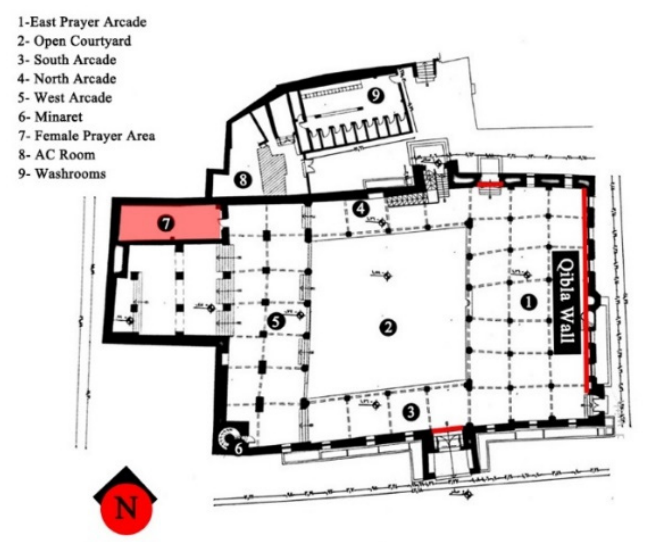

Figure 1: Al-Shafi'i Mosque Layout. (Source: Atlas of historic mosques, 2019.)

Al-Shafi'i Mosque is characterized by the presence of a large courtyard with an area of 305 square meters, which constitutes the majority of the space designated for prayer. All spaces within the mosque overlook this courtyard, which enhances the indoor ventilation and the availability of natural lighting. During daytime, the natural light in the courtyard is sufficient to create a general level of lighting for the indoor spaces, but during night-prayer, the dependence would be on the artificial lighting, which a high contrast in lighting distribution and illumination. The mosque is distinguished by its multiple number of wide windows that are rectangular in shape. They are made out of wood and glass and covered from the outside with iron grills and topped with small lantern windows and pointed arches. The mosque contains many stairs, which are elements of communication and movement between the different parts of the mosque. The Shafi'i Mosque has five main entrances distributed over the four facades of the mosque, and the main entrance is located in the middle of the south-oriented wall. The minaret is located southwest of the mosque and was built of carved stone and its height from the surface of the ground is about $24 \mathrm{~m}$ and it consists of a square base topped with three floors of an octagonal shape and ends with a round spire topped 
by the crescent (Fig. 2). Each floor of the minaret in two of the sides of the octagon has a lantern window, and in the third side there is a small door inserted that was dedicated to the exit of the muezzin to the balcony to call for prayer. The minaret is interspersed with some small openings for ventilation and lighting.

The mosque has a dome in the shape of an octagonal lantern loaded onto wooden legs that have been covered from the outside with lead boards (Fig. 3). The mosque was roofed with wooden squares stacked horizontally at equal distances bearing a layer of wooden boards topped with a cement layer and a layer of basalt stone.

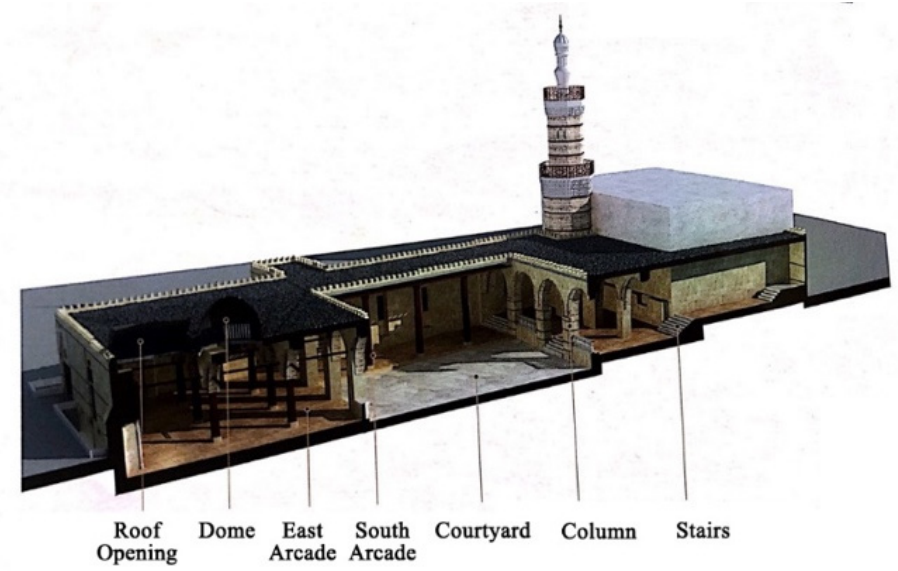

Figure 2: Al-Shafi'i Mosque architectural components. (Source: Atlas of Historic Mosques, 2019.)

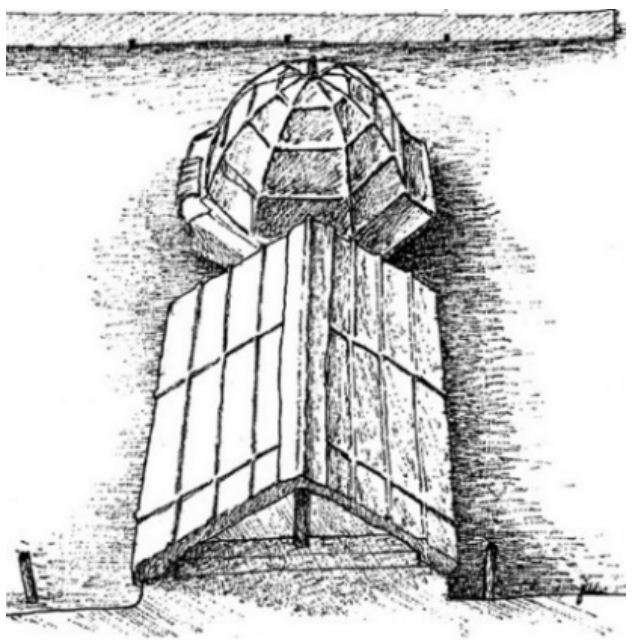

\section{Roof Dome and Opening}

Figure 3: Dome design at Al-Shafi'i Mosque. (Source: Atlas of Historic Mosques, 2019.) 
The mihrab of the mosque is located in the canopy of the dome in the middle of the qibla wall, which is hollow in shape, topped by interlaced circular arches (Fig. 4). Between them a stone pillar holds two circular arches and ascends to it through a wooden staircase and stands out from the top in a semi-circular shape surrounded by a wooden railing. During the restoration work, an old mihrab at a depth of $2 \mathrm{~m}$ was found under the existing mihrab of the mosque and was preserved and covered with glass to enable it to be seen.

The last restoration of the mosque was 500 years ago, and since that time, there had been no restoration until King Abdullah bin Abdelaziz, King of the Kingdom of Saudi Arabia, instigated the restoration of the mosque in 2012 under the supervision of the Ministry of Islamic Affairs (Fig. 5). Several problems were observed in the distribution of artificial lighting in the building, even after the restoration of the mosque. These defects included the use of color and the glow of inappropriate lighting, and the use of chandeliers and suspended lighting that resemble the shape of lanterns and the presence of ground lighting in the courtyard. This led to fail to take advantage of windows and the proper introduction of natural light.

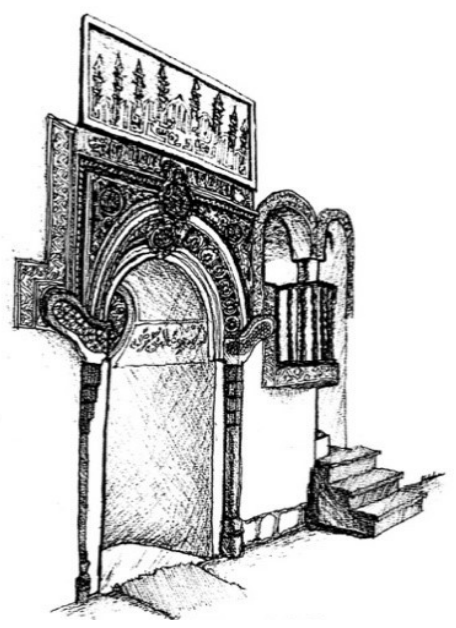

Figure 4: Mihrab at Qibla wall. (Source: Atlas of Historic Mosques, 2019.)
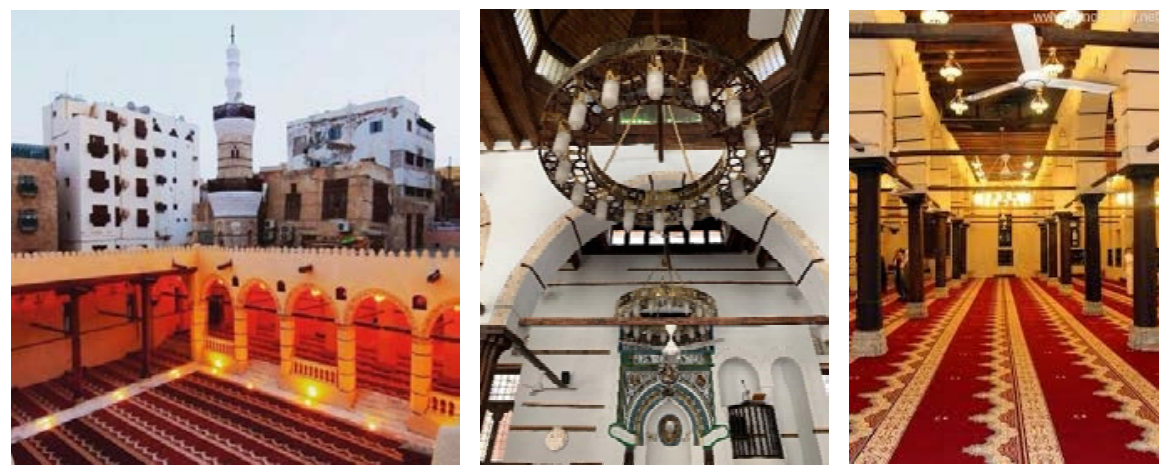

Figure 5: Al-Shafi'i Mosque after King Abdullah bin AbdulAziz restoration. (Source: Google Images, 2020.) 


\subsection{Al-Farsi Mosque}

Al-Farsi Mosque (Fig. 6), also referred to as Ruwais Mosque, was the result of a collaboration between the Ministry of Pilgrimage and Endowment and Jeddah Municipality with an objective of reviving traditional vocabularies and introducing new vocabularies to the design of mosques in Saudi Arabia, but in keeping with the historical architectural Islamic character [7].

The commission was originally to produce a number of sculptures along the Jeddah Corniche; however, this was changed to include a number of small mosques that possess artistic features. Al-Farsi Mosque was one of these mosques that showcases sculptural qualities which differ from traditional models. It was designed in 1980, by the architect Abdel Wahed El-Wakil, who was trained by Hassan Fathy, known for his passion for traditional character, local building materials and construction techniques that integrate with the local context [8].

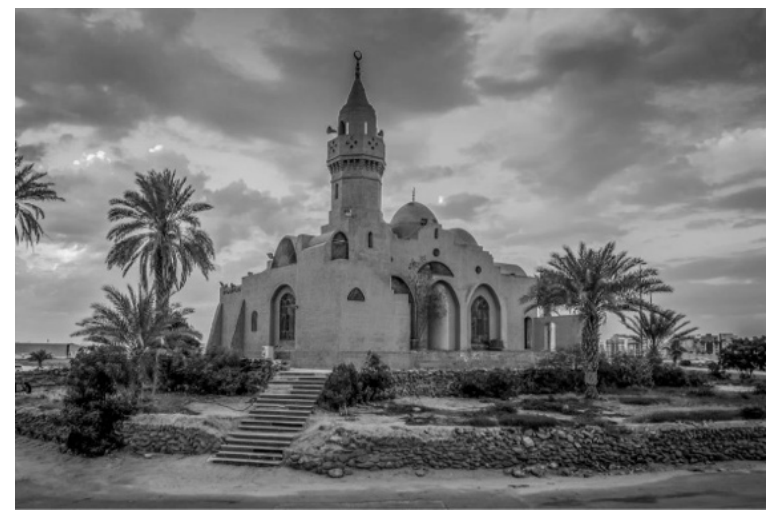

Figure 6: Al-Farsi Mosque: Located off Jeddah Corniche. (Source: Aga Khan Award for Architecture, 1989.)

The mosque is situated on a small hill off the Jeddah Corniche; features that provided the opportunity to utilize cool sea breeze for natural ventilation and cooling of the mosque indoors. Therefore, the design and architectural features of Al-Farsi Mosque were developed as a response to the natural available forces and climatic conditions. The entrance court of the mosque is covered with a series of wave-like brick vaults reflecting the movement of sea waves close to where the mosque is located. This movement in structure enforces the notion of breaking the old strict traditional form and reviving the Islamic identity in a modernized way.

The design of the Al-Farsi Mosque is influenced by the architectural vocabularies of the Mamluk period. Architecturally, the mosque utilizes a combination of simple forms; it has a rectangular floor plan layout covered with structural-vaults that carry octagonal-shaped pendentives supporting three circular domes. These three domes are lined along the Qibla Wall facing the East orientation. This structure is flanked by a Mamluk-style minaret. It has an octagonal shape that graduates in size to the spire (Fig. 7). The structural system is based on the utilization of hollow baked bricks, columns, vaults, domes and load-bearing walls and columns. The mosque was built with local materials showcasing craftsmanship and originality. 
However, some alterations were made to the mosque and the current situation of Al-Farsi Mosque features different characteristics from those originally intended:

- Most of the brick surfaces were covered with white plaster.

- The open vaulted domes designed for admitting daylight and natural ventilation were closed with glazing, due to the increasing automobile emissions and, consequently, the increasing levels of thermal heat. This has resulted in a complete dependence on mechanical conditioning systems for indoor cooling. In addition, these openings were shaded using wooden screens, which reduced the penetration of daylight into the indoor space, and subsequently, increased the need for and use of artificial lighting.

- The prayer hall has undergone alterations and the addition of internal divisions since the mosque was built. A part of the prayer hall was designated for females, which reduced the space in the men's section (Fig. 8).

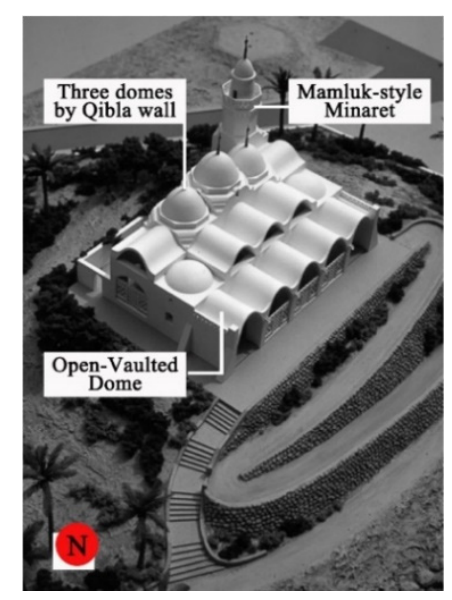

Figure 7: Al-Farsi Mosque elements. (Source: Aga Khan Award for Architecture, 1989.)

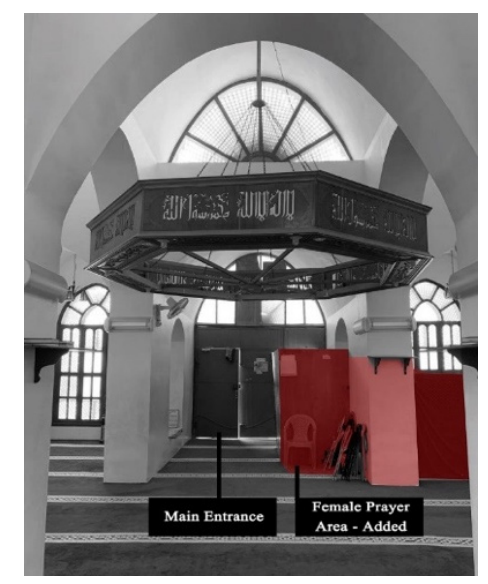

Figure 8: Female prayer area next to the main entrance. (Source: A Study by Research Team at King AbdulAziz University, 2019.) 
The roof design featured two-sets of repetitive brick vaults that create two series of sideopened domes. This assists in admitting daylight and originally allowed for natural ventilation to occur. In fact, this roof design unifies the space of prayer and creates an environment of great serenity. Moreover, daylight entering through the open vaulted roof strengthens the feeling of union among the believers and revives the sense of space communion.

Two windows are placed on either side of Mihrab in the Qibla wall (Fig. 9), as well as other multiple wall windows which were included in the design. The entering daylight is filtered and diffused by the wooden shading screens (Shish). This assists in providing minimum natural lighting with minimum glare.

Openings in the internal division walls create a sense of unity and belonging and help in ensuring a uniform distribution of daylight throughout the prayer hall. The daylight entering through roof and wall openings accentuates the geometrical features, arches and vaults of the mosque's ceiling and internal divisions (Fig. 10).

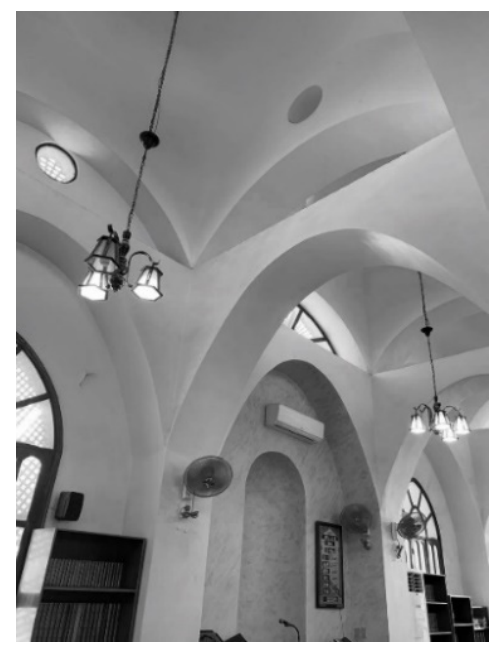

Figure 9: Windows on the sides of Mihrab in the Qibla Wall. (Source: A Study by Research Team at King AbdulAziz University, 2019.)

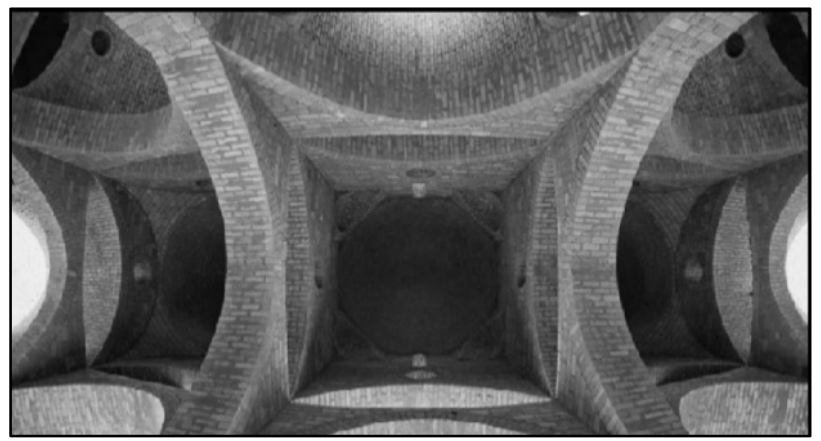

Figure 10: Daylight accentuates ceiling geometries and vaults. (Source: Aga Khan Award for Architecture, 1989.) 
In order to emphasize this and to indicate the Qibla wall in mosques, a small niche (Mihrab) was built for the Imam to pray and lead the prayers. Ornamentation of Mihrab usually indicates the influences from different periods of time; however, since the objective of Al-Farsi Mosque is to modernize the traditional mosque design, the Mihrab does not show any special indication or symbolic ornamentation. The Mihrab features modern design with a simple semi-circular arch and no decorative elements (Fig. 11).

The plan is organized in a way to respond to the Qibla wall, and the main entrance and spatial cores are planned around the Qibla axis. The Qibla Wall faces the main entrance (Fig. 12); therefore, people entering the mosque move directly in a simple short straight path with no rotations or angled path. This layout reduces the congregation's movement leading to entry in an orderly manner. In addition, this design attracts attention to the Qibla wall, and assists people in moving from the outside to the interior core of the mosque.

The Qibla wall consists of the Mihrab, wall recess, but the Minbar where imam usually stand to deliver lectures to the congregation, is absent. This can be attributed to the small size and prayer hall of the mosque.

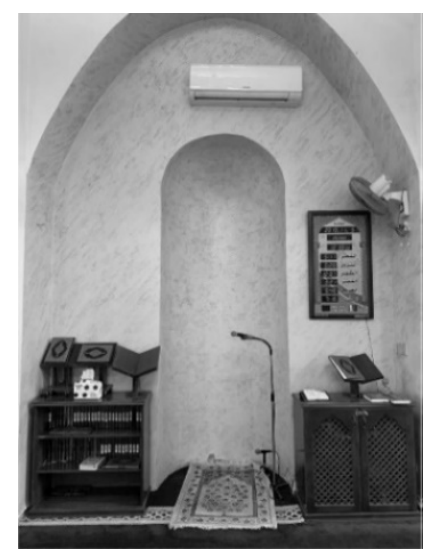

Figure 11: Simple modern Mihrab with no ornamentation at Al-Farsi Mosque. (Source: A Study by Research Team at King AbdulAziz University, 2019.)

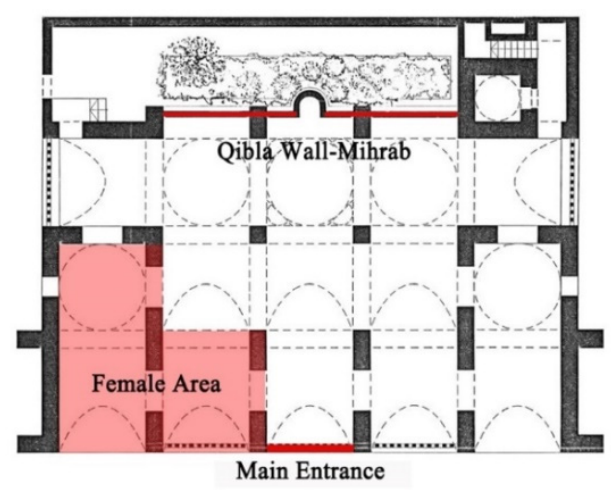

Figure 12: Al-Farsi Mosque floor plan showing Qibla wall facing the entrance. (Source: Aga Khan Award for Architecture, 1989.) 


\section{DISCUSSION}

A brief background, an analysis of mosques' spatial layout, and architectural elements were discussed in this article (refer to Table 1 for a detailed summary on both mosques). In addition, the influence of the Qibla orientation and lighting illuminance on the spatial layout and the design of architectural elements were investigated. There were differences observed including:

- Al-Shafi'i Mosque is inspired by the Hijaz style. On the other hand, Al-Farsi Mosque was inspired by the Mamluk architectural style.

- The mosques show varieties of Mihrab shapes/design.

- The amount of ornamentation on the Mihrab and Qibla wall differ between both mosques; it was highly-decorated in Al-Shafi'i Mosque as compared to the simple form in Al-Farsi Mosque.

- The mosques show varieties of Prayer Hall/overall mosque layouts.

- The mosques have traditional vernacular architectural features that respond to the local context.

These variations are probably due to the fact that each one is from a different period that have different ways of designing and implementation, influencing the mosques' physical looks and aesthetic features. Al-Farsi Mosque showcases new design vocabularies reviving the traditional Islamic image of the mosque.

Hassan and Arab [8] and Ghouchani et al. [9], reported that the central role of Qibla wall is to strengthen the Qibla direction, to create unity in the physical elements of mosque, as well as to attract the believers coming in at the entrance of mosque and influence their movement pattern. This was demonstrated in the Al-Farsi Mosque, where the Qibla wall is the first thing one can see when entering through the main entrance, which draws people in and influences their direction of travel.

The handling of daylight design in mosques depends mostly on the climatic conditions of location/context. In very hot climatic zones, daylight is admitted through small openings or filtered through openwork transenna panels/walls [10]. In Al-Shafi'i Mosque, the open inner courtyard and the side wall windows were the main source of daylight illumination as compared to Al-Farsi Mosque, where daylight was admitted through open-vaulted domes in the roof as well as side windows. Each source of daylighting conveys a unique feeling and serves a symbolic need. As pointed out by Fitoz and Berkin [6], a mosque should be illuminated with various forms of lighting in order to achieve the desired lighting effect serving religious and spiritual functions.

According to El-Darwish and El-Gendy [11], daylight should not enter from the Qibla wall to prevent causing glare and visual discomfort for worshippers facing the Qibla direction. Nevertheless, in Al-Farsi Mosque, two windows are placed on the sides of Mihrab in the Qibla wall, but with the presence of wooden shading screens (Shish); thus, the daylight is filtered, providing indoor natural lighting with minimum glare.

\section{CONCLUSION AND RECOMMENDATION}

The design and architecture of mosques are dynamic reflections shaped by the interaction of cultural structure, religious beliefs, socio-economic factors, politics, aesthetic values, technical considerations, context and geographical location. The architecture of mosques responds to the symbolic meaning and deep needs of religious believers This paper has specifically evaluated the types of structural design approaches that are employed in mosques to create the magnificent impact of light that give people the perception of existence. 
Table 1: Summary of the comparative analysis between case studies.

\begin{tabular}{|c|c|c|c|}
\hline \multicolumn{2}{|c|}{ Analysis Component } & \multirow{2}{*}{$\begin{array}{c}\text { Al-Shafi'i Mosque } \\
- \\
\end{array}$} & \multirow{2}{*}{$\begin{array}{c}\text { Al-Farsi Mosque } \\
\text { Abdel Wahid El-Wakil }\end{array}$} \\
\hline \multirow{7}{*}{ Background } & Architect & & \\
\hline & Year & $648 \mathrm{AH}$ & $1980-1400 \mathrm{H}$ \\
\hline & $\begin{array}{l}\text { Typology (historical, } \\
\text { Contemporary) }\end{array}$ & Historical & $\begin{array}{c}\text { Contemporary Reviving } \\
\text { traditional }\end{array}$ \\
\hline & $\begin{array}{l}\text { Main Components of } \\
\text { Mosque }\end{array}$ & $\begin{array}{l}\text { Prayer hall, Mihrab (niche), } \\
\text { Minaret (tower), Qubba } \\
\text { (dome), open courtyard }\end{array}$ & $\begin{array}{l}\text { Prayer hall, Mihrab (niche), } \\
\text { Minaret (tower), Qubba (dome) }\end{array}$ \\
\hline & Building Material & $\begin{array}{l}\text { Marine clay and excavated } \\
\text { stone blocks supported by } \\
\text { horizontal wooden beams } \\
\text { known as takhleh }\end{array}$ & $\begin{array}{l}\text { Hollow baked bricks, load bearing } \\
\text { walls and columns }\end{array}$ \\
\hline & $\begin{array}{c}\text { Floor plan Shape and } \\
\text { spatial layout }\end{array}$ & Rectangular layout & Rectangular layout \\
\hline & Influencing Period & $\begin{array}{l}\text { Hijaz style, inspired by } \\
\text { Ottoman period }\end{array}$ & Mamluk \\
\hline \multirow{4}{*}{$\begin{array}{l}\text { Elements of } \\
\text { Qibla Wall }\end{array}$} & Minbar & Yes & Not available \\
\hline & Mihrab & Yes & Yes \\
\hline & Openings availability & A number of wall windows & $\begin{array}{l}2 \text { wall windows on the sides of } \\
\text { Mihrab }\end{array}$ \\
\hline & Proximity to entrance & $\begin{array}{l}\text { five main entrances distributed } \\
\text { over the four facades of the } \\
\text { mosque }\end{array}$ & Facing the main entrance \\
\hline \multirow{3}{*}{$\begin{array}{l}\text { Emphasis on } \\
\text { Qibla wall }\end{array}$} & $\begin{array}{l}\text { Level of Emphasis: } \\
\text { (weak, normal, strong) }\end{array}$ & Strong & Normal \\
\hline & $\begin{array}{l}\text { How it is achieved: } \\
\text { (through ornamentation, } \\
\text { motifs, materiality, } \\
\text { lighting, color) }\end{array}$ & $\begin{array}{l}\text { The Mihrab is extensively } \\
\text { decorated with complex motifs } \\
\text { and colors }\end{array}$ & $\begin{array}{l}\text { The design of Mihrab is simple } \\
\text { and modern with no motifs or } \\
\text { special type of finish }\end{array}$ \\
\hline & $\begin{array}{l}\text { Influences gained: (axis } \\
\text { of movement, openings } \\
\text { location, type of finish } \\
\text { and materiality) }\end{array}$ & $\begin{array}{l}\text { Influencing axis of movement } \\
\text { and the finishing material and } \\
\text { design of Qibla wall }\end{array}$ & $\begin{array}{l}\text { Since it faces the main entrance, it } \\
\text { draws people toward the Qibla } \\
\text { wall influencing axis of } \\
\text { movement }\end{array}$ \\
\hline \multirow{4}{*}{ Openings } & $\begin{array}{c}\text { Type: } \\
\text { (window, dormer, } \\
\text { skylight, small ornamental } \\
\text { openings) } \\
\end{array}$ & $\begin{array}{l}\text { Multiple number of openings } \\
\text { (windows) }\end{array}$ & $\begin{array}{l}\text { Roof open vaulted-domes } \\
\text { And side wall windows }\end{array}$ \\
\hline & Location & Wall & Roof and Wall \\
\hline & $\begin{array}{l}\text { Treatment: (shish, shading } \\
\text { panels, glazing property, } \\
\text { window treatment/curtain) }\end{array}$ & $\begin{array}{l}\text { rectangular in shape of wood } \\
\text { and glass and covered from the } \\
\text { outside with iron and topped } \\
\text { with small lantern windows and } \\
\text { pointed arches. }\end{array}$ & $\begin{array}{l}\text { Wooden Shish panels, which } \\
\text { reduced the amount of penetrated } \\
\text { daylight }\end{array}$ \\
\hline & $\begin{array}{l}\text { Material (wood, } \\
\text { aluminum) }\end{array}$ & Wood, glass and iron & Wood frames \\
\hline \multirow{4}{*}{ Daylight } & Influences & $\begin{array}{l}\text { Entering the appropriate } \\
\text { amount of sunlight }\end{array}$ & $\begin{array}{l}\text { Abundant amount available due to } \\
\text { location }\end{array}$ \\
\hline & Source: (roof, wall) & an inner courtyard & Roof and wall \\
\hline & Availability & Yes & Yes, but reduced due to Shish \\
\hline & Distribution & $\begin{array}{l}\text { Good distribution due to the } \\
\text { presence of open courtyard }\end{array}$ & - \\
\hline
\end{tabular}


The use of light has an essential role in creating physiological and psychological effects, as well as emphasizing significant architectural elements. In addition, the quality, quantity and color of illumination accompanied with shadow all affect the quality and function of sacred spaces along with setting the mood for worshiping and spirituality.

The openings are an important design element that integrates with artificial lighting to create a variety of lighting levels within the single space of the mosque. In terms of artificial ceiling lighting, an appropriate lighting distribution must be adopted based on the distribution of interior spaces, public and secondary places, and the use of sustainable, safe and long-life lighting types. It is essential to pay attention to the internal space of the mosque rather than external architectural features since most of the religious activities are held inside time [10]. Therefore, more attention should be given to the lighting qualities in the mosques to highlight the distinctive designs and strive to comfort the users and worshipers and give them calm and tranquillity through the design of indoor lighting in the mosques.

Two examples of ancient and modern mosques were investigated in this study according to the ways in which they have been lighted interiorly. The purpose of this paper was to investigate the opportunities for providing sufficient daylighting in two mosques from different eras, through the design of openings' in terms of their location and orientation. The use of artificial lighting in these mosques' interiors and its design, including the direction and distribution of the lighting has also been discussed. It was concluded that the use of daylight in mosques needs more consideration and how efficient lighting techniques can be applied to minimize the use of artificial light sources during the day, while still providing a comfortable visual environment.

\section{ACKNOWLEDGEMENT}

This research did not receive any specific grant from funding agencies in the public, commercial, or not-for-profit sectors.

\section{REFERENCES}

[1] Bolak, O., A Research on Mosque Lighting, Istanbul Technical University: Istanbul, p. 4, 1967.

[2] Al-Raddadi, T., Design Standards For Natural Lighting in Mosques. Research Seminar On Mosque Architecture, King Saud University: Riyadh, 1999.

[3] Neufert, E., Architectural Data, Iowa Blackwell Publications: USA, 2000.

[4] Alturki, I., Schiler, M. \& Boyajian, Y., Improving Daylight in Mosques, 2006. www.usc.edu/dept/architecture/mbs/papers/ecs/96_mosques/mosques_96.html.

[5] Eco, U., Art and Aesthetics in Middle Ages, Can Publications: Istanbul, pp. 77-273, 1998.

[6] Fitoz, I. \& Berkin, G., Space Light \& Beliefs: The Use of Daylighting in Churches and Mosques, 2007. www.researchgate.net/publication/256715298.

[7] Abel, C., Model and metaphor in the design of new building types in Saudi Arabia. Theories and Principles of Design in the Architecture of Islamic Societies, ed. M.B. Sevcenko, Aga Khan Program for Islamic Architecture: Cambridge, MA 1988.

[8] Hassan, A. \& Arab, Y., Analysis of lighting performance between single dome and pyramid roof mosque in Mostar, Bosnia Herzegovina. Procedia - Social and Behavioral Sciences, 91, pp. 1-12, 2013.

[9] Ghouchani, M., Taji, M. \& Kordafshari, F., The effect of qibla direction on the hierarchy of movement in mosque: A case study of mosques in Yazd, Iran. Frontiers of Architectural Research, 8, pp. 396-405, 2019.

[10] Stegers, R., Sacred Buildings: A Design Manual, 1st ed., Birkhäuser: Berlin, 2008. 
[11] El-Darwish, I. \& El-Gendy, R., The role of fenestration in promoting daylight performance: The mosques of Alexandria since the 19th century. AEJ - Alexandria Engineering Journal, 55(4), pp. 3185-3193, 2016. 